\title{
Welcome to Agriculture \& Food Security
}

\author{
Malcolm Elliott ${ }^{1 *}$, Molly Jahn² and Magdy Madkour ${ }^{3}$
}

\section{Editorial}

Senior scientists from many countries have come together to meet the need for an open access research journal that focuses explicitly on agriculture, the condition of food security and the critical linkages between these topics. In the $21^{\text {st }}$ century, we recognize the dual role of agriculture as our species' lifeline for food and essential materials, as well as the dominant form of terrestrial planetary care, and the journal will facilitate the dissemination of information in this vitally important area of research.

Norman Borlaug (1914-2009) was awarded the Nobel Peace Prize in 1970 for initiating the Green Revolution in agriculture which increased agricultural production so successfully as to enable some one billion people, who would otherwise have died from starvation, to thrive. That said, it must be noted that in his Nobel Peace Prize Acceptance Speech (December the 11th, 1970) [1], he observed that:

"The green revolution has won a temporary success in man's war against hunger and deprivation; it has given man a breathing space. If fully implemented, the revolution can provide sufficient food for sustenance during the next three decades. But the frightening power of human reproduction must also be curbed; otherwise the success of the green revolution will be ephemeral only." The harsh reality of this warning was recognised in the early part of 2008 when the price of wheat and maize doubled and that of rice tripled, leading to food riots in 20 countries.

The Editors bring diverse perspectives to the challenge Norman Borlaug and his generation left in the wake of the Green Revolution, but several points are inescapably clear. There is broad agreement that food security is a goal of paramount importance in the $21^{\text {st }}$ century, and that food and food systems are critically important to humans far beyond the physical survival they provide. A sharp focus on productivity of familiar crops will continue to be essential using all technical and conceptual approaches that make sense to increase yields, improve crop and livestock efficiencies and overall agricultural systems outputs, and

\footnotetext{
*Correspondence: prof.m.elliott@gmail.com

${ }^{1}$ Founding Director, The Norman Borlaug Institute for Global Food Security, Leicester, UK

Full list of author information is available at the end of the article
}

improve outcomes in all dimensions including livelihoods and human health.

And as Norman Borlaug warned, humankind's numbers continue to increase so rapidly that, according to the United Nations' demographers, the world's population reached seven billion at the end of October, 2011 [2]. The UN FAO estimated that, in 2010, more than a billion people went to bed hungry or starving every night [3]. Indeed, this journal's inaugural issue aligns with the release of the final report from the Commission on Sustainable Agriculture and Climate Change, an initiative of the CGIAR Research Program on Climate Change, Agriculture and Food Security (CCAFS) (http://www.ccafs.cgiar.org/), entitled 'Achieving Food Security in the Face of Climate Change' [4], which emphasizes through seven key recommendations that an integrated approach must balance how much food we produce toward the outcome of nutritional security in the face of changing climate, and how much agriculture will contribute to further climate change. The Commission also launched a short animation "How to feed the world in 2050: actions in a changing climate" that illustrates the key actions that are necessary to put humanity in a 'safe operating space' for food security in 2050 (http://www.youtube. $\mathrm{com} /$ watch?feature=player_embedded\&v=gjtIl5B1zXI).

Borlaug himself championed the application of cutting edge science to crop production, and in this cause he espoused crop gene manipulation and other state-of-the-art genetic approaches. Dr Clive James, Borlaug's Deputy Director during his time at CIMMYT, has provided detailed reports of the progress in these approaches since their first application to agriculture in 1996. His latest video report is at http://www.isaaa.org/resources/videos/global statusreport2011. While there are many approaches to improving and stabilizing agricultural yields and livelihoods and the resilience of agricultural systems, the mandate of food security cuts across the debates. In every case, we hope this journal will advance our ability to account for our successes in agricultural research and food systems in terms of improved food security now and in the future.

It is apparent now in every sphere of discussion that includes agriculture, that agriculture must be "sustainable." We understand this to mean that our current agricultural practices across scales of time and space must 
be in long term balance, meeting human needs with healthy outcomes within the boundaries of our natural resource base. There is also growing recognition that agriculture's demands on the Earth system require new knowledge-intensive approaches that are founded in principles that guide local practices to manage specific, albeit uncertain, circumstances. We launch this journal as a way to deliver new science focused on agricultural and food systems, as well as new approaches to address critical human dimensions, new technologies, new ways of thinking and new ways to measure and manage attributes across dimensions and scales.

We are delighted to introduce Agriculture \& Food Security. Manuscripts submitted to this journal will be reviewed by internationally recognized experts in the appropriate fields, selected in part from our editorial board (http://www.agricultureandfoodsecurity.com/about/ edboard). Reviews of submitted manuscripts will be rapid and the suitability of manuscripts for publication will be assessed solely on criteria of scientific excellence. Online open access publication means that all articles will be available to all readers without charge immediately upon publication, and that films and animations are only a click away. A fixed article processing charge is paid on acceptance of an article and there are no extra charges for pages, colour, or supplementary data.

We emphasize that this journal will feature research outcomes within the field of food security with a particular focus on research that may inform more sustainable agriculture and food systems that better address local, regional, national and/or global food and nutritional insecurity. The journal will consider cutting-edge contributions across the breadth of relevant academic disciplines, including agricultural, ecological, environmental, nutritional, and socio-economic sciences, public health and policy.

We have commissioned three reviews for the launch, in the belief that they set the stage for the research papers we plan to publish in future, "Food security for Africa: an urgent global challenge" [5] is by Albert Sasson; "Impact of climate change on arid lands agriculture" [6] is by Adel ElBeltagy and Magdy Madkour and "The development of Brazilian agriculture: future technological challenges and opportunities" [7] is by Pedro A. Arraes Pereira, Geraldo B. Martha Jr, Carlos A.M. Santana and Eliseu Alves.

We intend that this journal will be a forum for scholars and practitioners working in familiar domains and across boundaries to share their work with peers and non-specialists. Further, we intend that this forum will promote rigorous scholarship focused on these attributes and dynamics of agricultural and food systems that will be so important looking forward as we set our sights on immediate and long term sufficiency.

\section{Author details}

'Founding Director, The Norman Borlaug Institute for Global Food Security, Leicester, UK. ${ }^{2}$ Professor, Laboratory of Genetics and Department of Agronomy, Center for Sustainability and the Global Environment, University of Wisconsin-Madison, Madison, USA. ${ }^{3}$ Professor of Biotechnology, Arid Lands Agricultural Research Institute, Faculty of Agriculture, Ain Shams University, Cairo, Egypt.

\section{Competing interest}

The author(s) declare that they have no competing interests.

Received: 30 March 2012 Accepted: 30 March 2012

Published: 19 April 2012

\section{References}

1. http://www.nobelprize.org/nobel_prizes/peace/laureates/1970/borlauglecture.html

2. http://www.nytimes.com/2011/11/01/world/united-nations-reports-7-billionhumans-but-others-dont-count-on-it.html? $r=1$

3. http://www.worldhunger.org/articles/Learn/world\%20hunger\%20facts\% 202002.htm

4. http://ccafs.cgiar.org/commission/reports\#inal

5. Sasson A: Food security for Africa: an urgent global challenge. Agriculture \& Food Security 2012, 1:2

6. El-Beltagy A, Madkour M: Impact of climate change on arid lands agriculture. Agriculture \& Food Security 2012, 1:3

7. Pereira PAA, Martha Jr GB, Santana CAM, Alves E: The development of Brazilian agriculture, future technological challenges and opportunities. Agriculture \& Food Security 2012, 1:4

doi:10.1186/2048-7010-1-1

Cite this article as: Elliott et al: Welcome to Agriculture \& Food Security. Agriculture \& Food Security 2012 1:1.

\section{Submit your next manuscript to BioMed Central and take full advantage of:}

- Convenient online submission

- Thorough peer review

- No space constraints or color figure charges

- Immediate publication on acceptance

- Inclusion in PubMed, CAS, Scopus and Google Scholar

- Research which is freely available for redistribution 